\title{
EFEKTIFITAS PEMUTARAN FILM TERHADAP PERILAKU BUANG SAMPAH PADA MAHASISWA AKPER MALAHAYATI MEDAN
}

\author{
Mona Hastuti \\ AKPER Malahayati Medan, Jl. Cendrawasih No. 161 Sei Sikambing B Medan
}

Email: monahastuti76@gmail.com

\begin{abstract}
ABSTRAK
Usia remaja merupakan masa transisi untuk menanamkan perilaku hidup bersih dan sehat (PHBS). Salah satu wujud PHBS adalah perilaku membuang sampah pada tempatnya. Tujuan penelitian ini adalah untuk menganalisis efektifitas pemutaran film terhadap perilaku buang sampah mahasiswa di Akper Malahayati. Jenis penelitian adalah quasi experiment dengan pendekatan kuantitatif dan desain one group pre test and post test design. Sampel adalah seluruh mahasiswa Akper Malahayati Medan tahun 2019 sebesar 32 orang. Pengumpulan data primer melalui kuesioner dan data sekunder melalui studi dokumentasi. Teknis analisis data secara univariat untuk memperoleh gambaran perilaku buang sampah dan analisis bivariat dengan menggunakan paired-sample $t$ test. Hasil penelitian menunjukkan pengetahuan siswa mayoritas baik $(68,8 \%)$, sikap mayoritas baik $(53,1 \%)$ dan tindakan mayoritas baik $(68,8 \%)$. Penerapan penyamapaian pesan melalui pemutaran film terbukti efektif terhadap peningkatan perilaku buang sampah mahasiswa (p<0,05). Peneliti menyarankan kepada Akper Malahayati Medan untuk lebih meningkatkan kesadaran mahasiswa untuk buang sampah pada tempatnya.
\end{abstract}

Kata Kunci : Pemutaran film, Perilaku buang sampah, Mahasiswa

\section{ABSTRACT}

Adolescence is a transition period to instill clean and healthy behavior (PHBS). One form of PHBS is the behavior of disposing garbage in its place. The purpose of this study was to analyze the effectiveness of film screenings on the behavior of students' garbage disposal in Akper Malahayati. This type of research is a quasi experiment with quantitative approach and one group pre-test and post-test design. The sample is all Medan Akper Malahayati students in 2019 amounting to 32 people. Primary data collection through questionnaires and secondary data through documentation studies. Univariate data analysis techniques to obtain a picture of waste disposal behavior and bivariate analysis using paired-sample $t$ tests. The results showed that the majority of students' knowledge was good (68.8\%), the majority's attitude was good $(53.1 \%)$ and the majority's actions were good (68.8\%). The application of message attainment through film screening proved to be effective in increasing the behavior of students' trash disposal ( $p$ $<0.05)$ The researcher suggested to Akper Malahayati Medan to further increase student awareness to dispose of trash in its place.

Keywords: Film Screenings, Garbage Disposal Behavior, College Students

\section{PENDAHULUAN}

Perilaku hidup bersih sehat (PHBS) di sekolah adalah untuk memberdayakan siswa, guru dan masyarakat lingkungan sekolah agar tahu, mau dan mamu mempraktikkan PHBS dan berperan aktif dalam mewujudkan sekolah sehat. PHBS juga merupakan sekumpulan perilaku yang dipraktikkan oleh peserta didik, guru dan masyarakat lingkungan sekolah atas dasar kesadaran sebagai hasil pembelajaran, sehingga secara mandiri mampu mencegah penyakit, meningkatkan kesehatannya, serta berperan aktif dalam mewujudkan lingkungan sehat (Depkes, 2010). Salah satu wujud kesehatan adalah perilaku kesehatan lingkungan yaitu bagaimana seseorang merespon lingkungan, baik lingkungan fisik maupun sosial budaya, dan sebagainya (Hidayat, 2009).

Dikaitkan dengan topik penelitian ini adalah perilaku membuang sampah oleh mahasiswa di kampus. Sampah di lingkungan pendidikan umumnya berwujud kertas, botol plastik, dan sampah bekas bungkus makanan mahasiswa. Menurut Proverawati \& Rahmawati (2016), bahwa sampah berdasarkan asalnya digolongkan dalam dua bagian yaitu sampah organik (sampah basah) dan sampah an-organik (sampah kering). Selain itu sampah dihasilkan dari beberapa sumber utama antara lain rumah tangga, sampah domestik 
yaitu sampah berupa sisa makana, bahan dan peralatan yang sudah tidak dipakai lagi, bahan pembungkus, kertas, plastik dan sebagainya.

Upaya promotif bisa melalui beberapa metode antara lain melalui pemutaran film, ceramah dan diskusi. Teman sebaya (peer group) merupakan suatu kelompok kecil yang anggotanya berusia relatif sama dan diantara mereka itu terjalin keakraban. Kelompok sebaya memberi remaja perasaan saling memiliki, pembuktian dan kesempatan untuk belajar perilaku yang dapat diterima. Rasa memiliki merupakan hal yang penting karena dikritik atau diabaikan oleh teman sebaya menimbulkan perasaan inferior, tidak adekuat dan tidak kompeten. Oleh karena itu remaja akan berperilaku dengan cara yang akan memperkuat keberadaan mereka di dalam kelompok (Potter \& Perry, 2009).

Teori perubahan perilaku yang berkaitan dengan perilaku mahasiswa membuang sampah sembarangan diacu dari teori perubahan perilaku menurut Glanz et al (2008), yang menyatakan perilaku ditentukan oleh: 1) sikap yang mendorong perilaku (attitude toward the behavior) yaitu keyakinan dan konsekuensi serta evaluasi perilaku siswa membuang sampah; 2) norma subjektif (subjective norms) yaitu fungsi dari harapan yang dipersepsikan individu saat satu atau lebih orang di sekitarnya (misalnya, saudara, teman sejawat) menyetujui perilaku tertentu dan memotivasi individu tersebut untuk mematuhi mereka; 3) kontrol perilaku persepsian (perceive behavior control) sebagai persepsi kemudahan atau kesulitan untuk melakukan perilaku; dan 4) niat (intention) yaitu cerminan motivasi pihak sekolah dan tenaga kesehatan dari fasilitas kesehatan setempat untuk mempengaruhi perilaku siswa membuang sampah pada tempatnya.

Penelitian sejenis yang pernah dilakukan sebelumnya yaitu penelitian Permana (2014), tentang pengaruh pendidikan kesehatan melalui teman sebaya (peer group) terhadap sikap remaja tentang HIV/AIDS di SMAN 2 Bantul Yogyakarta. Hasil penelitian ini menunjukkan bahwa ada pengaruh pendidikan kesehatan melalui teman sebaya (peer group) terhadap sikap remaja tentang HIV/AIDS.

Hasil studi pendahuluan yang dilakukan di Akper Malahayati Medan, permasalahan sampah masih menjadi satu permasalahan yang perlu ditingkatkan. Lingkungan kampus terlihat masih belum memenuhi syarat lingkungan yang sehat karena ditemukan banyak sampah yang pada umumnya berasal dari kertas bekas dan bungkus bekas wadah makanan mahasiswa serta sisa makanan yang tidak habis dimakan. Mahasiswa masih ada yang membuang sampah sembarangan atau tidak pada tempatnya, pada hal pihak institusi sudah menyediakan tempat pembuangan sampah. Petugas kebersihan ada 2 orang yang bila dibandingkan dengan luas wilayah kampus tidak sebanding, sehingga terkesan tidak mampu melaksanakan tugasnya sebagaimana mestinya.

Hasil wawancara dengan petugas kebersihan diperoleh informasi bahwa mahasiswa cenderung membuang sampah sembarangan dan bila ketahuan lalu ditegur mereka memungutnya dan membuang ke tempat sampah tetapi keesokan harinya bisa terulang kembali. Walaupun setiap hari diingatkan dan dinasehati, namun mahasiswa tetap membuang sampah sembarangan. Hasil wawancara dengan beberapa mahasiswa diperoleh informasi bahwa mereka membuang sampah sembarangan karena tempat sampah jauh dan malas membuangnya ke tempat sampah.

Berdasarkan uraian latar belakang dan fenomena di lokasi penelitian maka peneliti ingin melakukan penelitian tentang efektifitas pemutaran film terhadap perilaku buang sampah pada mahasiswa Akper Malahayati Medan.

\section{METODE PENELITIAN}

Tujuan penelitian untuk menganalisis efektifitas pemutaran film terhadap perilaku buang sampah mahasiswa di Akper Malahayati. Jenis penelitian adalah quasi experiment dengan pendekatan kuantitatif dan desain one group pre test and post test design. Sampel adalah seluruh mahasiswa Akper Malahayati Medan tahun 2019 sebesar 32 orang. Pengumpulan data primer melalui kuesioner dan data sekunder melalui studi dokumentasi. Teknis analisis data secara univariat untuk memperoleh gambaran perilaku buang sampah dan analisis bivariat dengan menggunakan paired-sample t test. 


\section{HASIL}

Tabel 1. Karakteristik Responden

Berdasarkan Umur dan Jenis Kelamin pada Mahasiswa di Akper Malahayati Medan

\begin{tabular}{clcc}
\hline No. & Karakteristik & n & \% \\
\hline 1. & Umur & & \\
\hline & 18 Tahun & 11 & 34,3 \\
\hline & 19 Tahun & 10 & 31,4 \\
\hline & 20 Tahun & 11 & 34,3 \\
\hline & Total & 32 & 100 \\
\hline 2. & Jenis Kelamin & & \\
\hline & Laki-laki & 10 & 31,3 \\
\hline & Perempuan & 22 & 68,8 \\
\hline & Total & 97 & 100 \\
\hline
\end{tabular}

Berdasarkan tabel 1, hasil penelitian menunjukkan bahwa karakteristik responden menurut umur mayoritas berumur 18 dan 20 tahun masing-masing sebanyak 11 orang $(34,3 \%)$ selebihnya berumur 19 tahun sebanyak 10 orang $(31,4 \%)$. Hasil penelitian juga menunjukkan bahwa karakteristik responden menurut jenis kelamin mayoritas berjenis kelamin perempuan sebanyak 22 orang $(68,8 \%)$ dan selebihnya berjenis kelamin laki-laki sebanyak 10 orang $(31,3 \%)$.

Tabel 2. Distribusi Frekuensi Responden

Berdasarkan Pengetahuan, Sikap, dan

Tindakan Buang Sampah Sebelum Intervensi dengan Pemutaran Film di Akper Malahayati

\begin{tabular}{ccc}
\hline Pengetahuan & $\mathbf{n}$ & $\mathbf{\%}$ \\
\hline Baik & 22 & 68,8 \\
\hline Kurang Baik & 10 & 31,2 \\
\hline Total & 32 & 100 \\
\hline Sikap & & \\
\hline Baik & 17 & 53,1 \\
\hline Kurang Baik & 15 & 46,9 \\
\hline Total & 32 & 100 \\
\hline Tindakan & & \\
\hline Baik & 22 & 68,8 \\
\hline Kurang Baik & 10 & 31,2 \\
\hline Total & 32 & 100 \\
\hline
\end{tabular}

Berdasarkan tabel 2, hasil penelitian menunjukkan bahwa pengetahuan responden mayoritas berpengetahuan baik yaitu sebesar $68,8 \%$, sedangkan pengetahuan kurang baik sebesar $31,2 \%$. Pengetahuan responden yang mayoritas baik tentang perilaku buang sampah diakibatkan informasi yang diperoleh mahasiswa benar-benar mampu menarik minat mahasiswa untuk mengetahui dengan baik tentang perilaku buang sampah pada tempatnya. Hal ini terbukti dari jawaban mahasiswa terhadap pernyataan pada kuesioner yang menunjukkan siswa sudah mengerti dan memahami bahwa sampah yang berserakan tidak baik bagi kesehatan dan dapat merusak keindahan lingkungan kampus.

Berdasarkan tabel 2, hasil penelitian menunjukkan bahwa sikap responden mayoritas baik yaitu sebesar 53,1\%, sedangkan sikap kurang baik 46,9\%. Sikap responden yang mayoritas baik terhadap perilaku membuang sampah dibuktikan dari respon mahasiswa saat ditegur bila kedapatan membuang sampah sembarangan. Mahasiswa cenderung berespon dengan baik anjuran yang diberikan dosen untuk membuang sampah pada tempatnya, namun tanpa mengetahui dengan baik apa dampak dari perilakunya membuang sampah sembarangan.

Berdasarkan tabel 2, hasil penelitian menunjukkan tindakan responden mayoritas tindakan buang sampah sembarangan baik yaitu $68,8 \%$, sedangkan tindakan kurang baik $31,2 \%$. Tindakan responden yang mayoritas tidak melakukan buang sampah sembarangan sudah cukup baik, namun bila dilihat dari persentase jumlahnya, masih cukup besar jumlah mahasiswa yang membuang sampah sembarangan (31,3\%). Beberapa mahasiswa sesuai hasil jawaban pada kuesioner masih ada yang saat membuang sampah dan jatuh di luar tempat sampah membiarkannya saja dan masih ada mahasiswa yang saat menyapu kelas membuang sampah ke halaman begitu saja bukan ke tempat sampah yang telah disediakan. Hal ini membuktikan perlu upaya pengurangan jumlah mahasiswa yang membuang sampah sembarangan.

Tabel 3. Distribusi Frekuensi Responden

Berdasarkan Pengetahuan, Sikap, dan Tindakan Buang Sampah Setelah Intervensi dengan Pemutaran Film di Akper Malahayati

\begin{tabular}{ccc}
\hline Pengetahuan & n & \% \\
\hline Baik & 29 & 90,6 \\
\hline Kurang Baik & 3 & 9,4 \\
\hline Total & 32 & 100 \\
\hline Sikap & & \\
\hline Baik & 17 & 53,1 \\
\hline Kurang Baik & 15 & 46,9 \\
\hline Total & 32 & 100 \\
\hline Tindakan & & \\
\hline Baik & 29 & 90,6 \\
\hline Kurang Baik & 3 & 9,4 \\
\hline Total & 32 & 100 \\
\hline & &
\end{tabular}


Berdasarkan tabel 3, hasil penelitian menunjukkan bahwa pengetahuan responden setelah intervensi dengan pemutaran film mayoritas berpengetahuan baik yaitu sebesar $90,6 \%$. Pengetahuan responden yang mayoritas baik tentang perilaku buang sampah setelah dilakukan intervensi yaitu pemutaran film diakibatkan informasi yang diperoleh siswa benar-benar mampu menarik minat mahasiswa untuk serius memperhatikan terutama pemutaran sangat menarik perhatian para mahasiswa.

Berdasarkan tabel 3, hasil penelitian menunjukkan bahwa sikap responden setelah intervensi dengan pemutaran film mayoritas baik yaitu sebesar $53,1 \%$. Sikap responden mayoritas baik setelah intervensi dilakukan dibuktikan mahasiswa yang mayoritas menyatakan tidak nyaman melihat sampah yang berserakan di ruang kelas, senang melihat teman yang membuang sampah pada tempatnya dan merasa bangga jika membuang sampah di tempat yang telah disediakan.

Berdasarkan tabel 3, hasil penelitian menunjukkan tindakan responden setelah diberikan intervensi dengan pemutaran film mayoritas tindakan buang sampah baik yaitu $90,6 \%$. Tindakan responden yang mayoritas baik dalam buang sampah dibuktikan dari jawaban mahasiswa yang tidak membuang sampah sembarangan lagi setelah ditegur oleh dosen, tidak mau meniru bila ada teman yang membuang sampah sembarangan, dan jika sampah yang dibuang mahasiswa ke tempat sampah jatuh di luar tempat sampah, mahasiswa mengambil lalu memasukkannya ke dalam tempat sampah kembali.

Tabel 4. Distribusi Perbedaan Pengetahuan, Sikap, dan Tindakan Buang Sampah Sebelum dan Setelah Intervensi dengan Pemutaran Film di Akper Malahayati

\begin{tabular}{|c|c|c|c|c|c|}
\hline \multirow{2}{*}{\multicolumn{2}{|c|}{ Variabel }} & \multicolumn{4}{|c|}{ Metode Pemutaran Film, Ceramah dan Diskusi } \\
\hline & & Mean & $S D$ & Mean Diff & P Value \\
\hline \multirow{2}{*}{ Pengetahuan } & Sebelum & 16,91 & 2,069 & \multirow{2}{*}{$-1,781$} & \multirow{2}{*}{0,001} \\
\hline & Setelah & 18,69 & 1,615 & & \\
\hline \multirow{2}{*}{ Sikap } & Sebelum & 32,00 & 5,322 & \multirow{2}{*}{$-3,031$} & \multirow{2}{*}{0,003} \\
\hline & Setelah & 35,03 & 4,381 & & \\
\hline \multirow{2}{*}{ Tindakan } & Sebelum & 17,56 & 2,271 & \multirow{2}{*}{$-0,563$} & \multirow{2}{*}{0,007} \\
\hline & Setelah & 18,13 & 1,792 & & \\
\hline
\end{tabular}

Berdasarkan tabel 4 , hasil penelitian dengan menggunakan uji paired $t$ test menunjukkan bahwa ada perbedaan pengetahuan responden sebelum intervensi yaitu nilai mean 16,91 dan setelah intervensi dengan pemutaran film menjadi 18,69 . Pengetahuan responden mengalami peningkatan setelah intervensi dengan metode pemutaran film dengan perbedaan rata-rata (mean difference) sebesar 1,656 dan $p$ value adalah 0,001 . Hal ini berarti bahwa secara statistik ada perbedaan yang signifikan $(p<0,05)$ antara pengetahuan sebelum dan segera setelah intervensi dengan metode pemutaran film.

Hasil penelitian juga menunjukkan bahwa ada perbedaan sikap responden sebelum intervensi yaitu nilai mean 32,00 dan setelah intervensi dengan metode pemutaran film, menjadi 35,03. Sikap responden mengalami peningkatan setelah intervensi dengan metode pemutaran film dengan perbedaan rata-rata (mean difference) sebesar 3,031 dan $p$ value adalah 0,003 . Hal ini berarti bahwa secara statistik ada perbedaan yang signifikan $(p<0,05)$ antara sikap sebelum dan segera setelah intervensi dengan metode pemutaran film.

Hasil penelitian juga menunjukkan bahwa ada perbedaan tindakan responden sebelum intervensi yaitu nilai mean 17,56 dan setelah intervensi dengan metode pemutaran film menjadi 18,13 . Tindakan responden mengalami peningkatan setelah intervensi dengan metode pemutaran film dengan perbedaan rata-rata (mean difference) sebesar 0,563 dan $p$ value adalah 0,007. Hal ini berarti bahwa secara statistik ada perbedaan yang signifikan $(p<0,05)$ antara tindakan sebelum dan setelah intervensi dengan metode pemutaran film.

\section{PEMBAHASAN}

Pengetahuan, Sikap, Dan Tindakan Responden Sebelum Intervensi Metode Pemutaran Film di Akper Malahayati Medan

Berdasarkan hasil analisis statistik, pengetahuan mahasiswa Akper Malahayati Medan tentang buang sampah menunjukkan 
mayoritas baik $(68,8 \%)$ dan kurang baik sebesar 31,3\%. Mahasiswa mayoritas memiliki pengetahuan yang baik. Hal ini dapat disebabkan mahasiswa ada memperoleh informasi baik dari orangtua/keluarga maupun dari media massa (elektronik dan cetak).

Hasil penelitian juga menunjukkan sikap mahasiswa Akper Malahayati Medan menunjukkan mayoritas baik $(53,1 \%)$ dan kurang baik (46,9\%). Masih banyaknya mahasiswa yang kurang baik sikapnya disebabkan oleh kurangnya pengetahuan sehingga berdampak pada sikap yang juga kurang baik.

Hasil penelitian juga menunjukkan tindakan mahasiswa Akper Malahayati Medan dalam membuang sampah menunjukkan mayoritas baik $(68,8 \%)$ dan dilakukan (31,3\%). Namun masih ada mahasiswa yang melakukan buang sampah sembarangan disebabkan kurangnya pengetahuan dan sikap baik tentang dampak dari membuang sampah sembarangan baik terhadap lingkungan sekolah dan dampaknya bagi kesehatan para siswa dan guru. Hal ini dibuktikan dari hasil jawaban responden pada pernyataan pada kuesioner yang menunjukkan siswa cenderung membuang sampah sembarangan karena ikut-ikutan pada teman.

Hasil penelitian ini pada variabel sikap sesuai dengan hasil penelitian Islamiyati (2014), yang menunjukkan sikap siswa tentang PHBS sebelum dilakukan pemberdayaan peer group dalam kategori baik. Hasil penelitian ini pada variabel pengetahuan juga menunjukkan kategori yang sama yaitu baik.

Bloom dalam Kholid (2014), membagi perilaku manusia dalam tiga domain yaitu kognitif, afektif, dan psikomotor. Domain kognitif diukur dari pengetahuan (knowledge). Pengetahuan diartikan sebagai hasil dari tahu dan ini terjadi setelah orang melakukan pengindraan terhadap suatu objek tertentu. Pengetahuan seseorang individu terhadap sesuatu dapat berubah dan berkembang sesuai kemampuan, kebutuhan, pengalaman dan tinggi rendahnya mobilitas informasi tentang sesuatu di lingkungannya. Domain afektif diukur dengan sikap (attitude). Sikap diartikan sebagai reaksi atau respon seseorang yang masih tertutup terhadap suatu stimulus atau objek, baik yang bersifat intern maupun ekstern sehingga tidak dapat langsung dilihat, tetapi hanya dapat ditafsirkan terlebih dahulu dari perilaku tertutup tersebut. Sikap secara realistis menunjukkan kesesuaian respon terhadap stimulus tertentu. Domain psikomotor diukur dari keterampilan (psychomotor/practice). Domain psikomotor yaitu tindakan diartikan sebagai suatu sikap optimis terwujud dalam suatu tindakan (overt behaviour). Untuk mewujudkan sikap menjadi suatu perbuatan nyata diperlukan faktor pendukung atau suatu kondisi yang memungkinkan, antara lain adalah fasilitas.

Berdasarkan analisis dan pembahasan hasil penelitian dapat disimpulkan bahwa sebelum dilakukan intervensi dengan metode pemutaran film terhadap mahasiswa Akper Malahayati Medan, masih banyak mahasiswa yang berperilaku kurang baik dalam hal membuang sampah di lingkungan sekolah. Perilaku yang kurang baik tersebut baik menyangkut pengetahuan tentang dampak membuang sampah sembarangan, sikap yang hanya merespon baik teguran dosen saat kedapatan membuang sampah sembarangan dan tindakan membuang sampah yang masih dilakukan bila tidak ada yang mengawasi.

Efektifitas Metode Pemutaran Film Terhadap Perilaku Buang Sampah pada Mahasiswa di Akper Malahayati Medan

\section{Pengetahuan}

Berdasarkan analisis statistik menggunakan paired-sample t test terdapat perbedaan yang bermakna sebesar 1,781 antara pengetahuan siswa sebelum intervensi (mean 16,91) dan pengetahuan mahasiswa setelah intervensi (mean 18,69) dengan metode pendidikan teman sebaya melalui pemutaran film dalam meningkatkan pengetahuan mahasiswa tentang perilaku membuang sampah sembarangan. Perbedaan tersebut dapat terlihat dari perbedaan mean pengetahuan mahasiswa sebelum dan setelah intervensi.

Hasil uji statistik dengan paired-sample $t$ test sebelum dan setelah intervensi dengan metode pemutaran film diketahui nilai $\mathrm{t}_{\text {hitung }}$ $=-3,688<\mathrm{t}_{\text {tabel }}=-2,042$. Hasil ini menunjukkan bahwa ada pengaruh metode penyampaian pesan dengan pengetahuan mahasiswa. Artinya, metode ini cukup efektif dalam meningkatkan perilaku 
mahasiswa dalam membuang sampah pada tempatnya di lingkungan kampus.

Berdasarkan analisis hasil penelitian dapat disimpulkan bahwa ada perbedaan yang bermakna antara pengetahuan mahasiswa sebelum dan setelah intervensi dengan metode pendidikan teman sebaya melalui pemutaran film menunjukkan bahwa metode pendidikan teman sebaya cukup efektif sehingga mampu dalam meningkatkan perilaku mahasiswa untuk membuang sampah pada tempatnya di lingkungan kampus.

\section{Sikap}

Berdasarkan analisis statistik menggunakan paired-sample t test terdapat perbedaan yang bermakna sebesar 3,031 antara sikap mahasiswa sebelum intervensi (mean 32,00) dan sikap siswa setelah intervensi (mean 35,03) dengan metode pendidikan teman sebaya melalui pemutaran film dalam meningkatkan pengetahuan mahasiswa tentang perilaku membuang sampah sembarangan. Perbedaan tersebut dapat terlihat dari perbedaan mean sikap mahasiswa sebelum dan setelah intervensi.

Hasil uji statistik dengan paired-sample $t$ test sebelum dan setelah intervensi dengan metode pendidikan teman sebaya melalui pemutaran film diketahui nilai $t_{\text {hitung }}=-3,206$ $<t_{\text {tabel }}=-2,042$. Hasil ini menunjukkan bahwa ada perbedaan yang bermakna antara sikap mahasiswa sebelum dan setelah intervensi.

Berdasarkan analisis hasil penelitian dapat disimpulkan bahwa adanya perbedaan yang bermakna antara sikap mahasiswa sebelum dan setelah intervensi dengan metode pendidikan teman sebaya melalui pemutaran film menunjukkan bahwa metode pendidikan teman sebaya cukup efektif.

\section{Tindakan}

Berdasarkan analisis statistik menggunakan paired-sample t test terdapat perbedaan yang bermakna sebesar 0,563 antara tindakan mahasiswa sebelum intervensi (mean 17,56) dan sikap siswa setelah intervensi (mean 18,13) dengan metode pemutaran film dalam meningkatkan pengetahuan mahasiswa tentang perilaku buang sampah. Perbedaan tersebut dapat terlihat dari perbedaan mean tindakan sebelum dan setelah intervensi.
Hasil uji statistik dengan paired-sample $t$ test sebelum dan setelah intervensi dengan metode pemutaran film diketahui nilai $t_{\text {hitung }}$ $=-3,879<\mathrm{t}_{\text {tabel }}=-2,042$. Hasil ini menunjukkan bahwa ada perbedaan yang bermakna antara tindakan mahasiswa sebelum dan setelah intervensi.

Berdasarkan analisis hasil penelitian dapat disimpulkan bahwa adanya perbedaan yang bermakna antara tindakan mahasiswa sebelum dan setelah intervensi dengan metode pemutaran film menunjukkan bahwa kombinasi metode pemutaran film cukup efektif sehingga mampu dalam meningkatkan perilaku mahasiswa buang sampah pada tempatnya di lingkungan kampus.

Hasil penelitian ini didukung oleh penelitian Adznan (2013), yang menemukan peran teman sebaya sebagian besar dalam kategori baik dan praktik Perilaku Hidup Bersih dan Sehat (PHBS) siswa sebagian besar dalam kategori baik. Terdapat hubungan yang bermakna antara peran teman sebaya dengan PHBS dengan PHBS anak di SD Negeri Kedungmundu Semarang.

Menurut Pujiastuti (2015) dalam penelitiannya menyatakan pendampingan peer group dalam mengajarkan PHBS cuci tangan memberi dampak yang sangat signifikan terhadap kemampuan cuci tangan siswa. Hal ini dikarenakan anak usia sekolah yang berada pada tahap pertengahan cenderung paling tinggi antusiasnya dalam aktivitas sosial bersama kelompok teman sebayanya. Sehingga timbul hubungan atau dukungan dari peer group yang dapat membantu dalam mengatasi masalah kesehatan.

Hasil penelitian ini menunjukkan bahwa metode pemutaran film dalam merubah perilaku mahasiswa buang sampah pada tempatnya. Hal ini terbukti dari perilaku mayoritas siswa mencakup pengetahuan, sikap dan tindakan membuang sampah pada tempatnya sudah baik. Para mahasiswa terlihat disiplin membuang sampah pada tempatnya dan sudah mengetahui dengan jelas perbedaan jenis sampah (organik dan nonorganik).

\section{KESIMPULAN}

Penerapan metode penyampaian pesan yaitu pemutaran film terbukti efektif terhadap peningkatan perilaku membuang 
sampah pada mahasiswa di Akper Malahayati Medan terbukti dari nilai signifikansinya $p<0,05$ sehingga memberikan dampak positif yang lebih nyata jika dibandingkan sebelum dilakukan intervensi.

\section{DAFTAR PUSTAKA}

Adznan. (2013). Faktor-faktor yang Berhubungan dengan Praktik Perilaku Hidup Bersih dan Sehat (PHBS) pada Siswa SD Negeri Kedungmundu Semarang. Manuscript. Prodi Ilmu Keperawatan. Universitas Muhammadiyah: Semarang.

Bani, A. (2016). Peran Pendidikan Kesehatan terhadap Perilaku Hidup Bersih Sehat (PHBS) Siswa Kelas Atas SD $\quad N \quad 1$ Kesugihan Kecamatan Kesugihan Kabupaten Cilacap. Skripsi. Universitas Negeri Yogyakarta.

Depkes, 2010. Rumah Tangga Sehat Dengan Perilaku Hidup Bersih dan Sehat. Kemenkes: Jakarta.

Glanz, Karen, Barbara K. Rimer, \& K. Viswanath. (2008). Health behaviour and health education.Jossey Bass, America.

Hidayat, D.R. (2009). Pengantar Psikologi untuk Tenaga Kesehatan. Ilmu Perilaku Manusia.
Islamiyati, N.K. (2014). Pengaruh Pemberdayaan Peer Group terhadap Perilaku Hidup Bersih dan Sehat pada Anak Sekolah Dasar Negeri Kasihan Ngentakrejo Lendah Kulon Progo. Naskah Publikasi. Prodi Ilmu Keperawatan STIKes Aisyiyah, Yogyakarta.

Kholid, A. (2014). Promosi Kesehatan: Dengan Pendekatan Teori Perilaku, Media dan Aplikasinya untuk Mahasiswa dan Praktisi Kesehatan. Cetakan Kedua. PT RajaGrafindo Persada: Jakarta.

Permana, R.T.W. (2014). Pengaruh Pendidikan Kesehatan melalui Peer Group terhadap Sikap Remaja tentang HIV/AIDS di SMAN 2 Bantul Yogyakarta. Naskah Publikasi. Prodi Ilmu Keperawatan. STIKes Aisyiyah: Yogyakarta.

Potter \& Perry. (2009). Fundamental of Nursing. Buku 1, Edisi 7, Salemba Medika, Jakarta.

Proverawati, A., \& Rahmawati, E. (2016). Perilaku Hidup Bersih dan Sehat (PHBS). Nuha Medika, Yogyakarta.

Prakoso, G. (2010). Pengetahuan Dasar Film Animasi. Fakultas Film Televisi Institut Kesenian Jakarta: Jakarta 